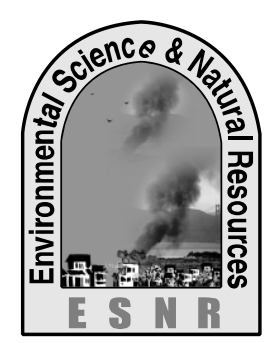

\title{
Organic and Inorganic Amendments on Rice (Oryza Sativa L.) and Soil in Salt Affected Areas of Bangladesh
}

\author{
M. B. Hossain * and R. R. Sarker
}

Soil Science Division, Bangladesh Institute of Nuclear Agriculture (BINA), Bangladesh

Agricultural University campus, Mymensingh, Bangladesh

*Corresponding author : belalbina@gmail.com

\begin{abstract}
Salinity is a limiting factor for growth and development, since it affects several physiological processes in plants. An experiment was conducted to evaluate rice yield and quality of soil using different organic and inorganic amendments. Field experiment was laid out in a randomized block design with three replications and six treatments. Each treatment was received recommended doses of chemical fertilizers also. Based on these results, $50 \%$ of rice straw and gypsum amendments could be recommended to mitigate soil salinity thereby, improving the crop productivity of the salt affected lands. Maximum plant height, panicle length, total and effective tillers per hill and filled grains per panicle were observed in 50\% (rice straw + gypsum) treated plots. Nutrients uptake were increased in grain and straw using different treatments compared to control and rice straw alone treated plots. In post harvest soil, there was a slight change of salinity and $\mathrm{pH}$ as affected by different treatments. Addition of rice straw and gypsum showed positive impact on organic carbon in soil.
\end{abstract}

Key words: Amendments, Crop productivity, Nitrogen and agronomic use efficiency, Problem soil, Rice yield

\section{Introduction}

Soil salinization is a major obstacle to the optimal utilization of land resources. Salt affected soils are widely distributed through the world and about $20 \%$ of the world's cultivated land is salt affected (Sumner, 2000). The coastal area of Bangladesh covers about $20 \%$ of the country and over $30 \%$ of the net cultivable area. Out of 2.85 million hectares of the coastal and offshore areas about 0.83 million hectares are arable lands which cover more then $30 \%$ of the total cultivable lands of Bangladesh (Haque, 2006). Sodium $\left(\mathrm{Na}^{+}\right)$is the dominant cation in saline soils which create physiological disturbance of crop (Qadir et al. 2007; Ribeiro et al. 2014). The tissues of plants growing in saline media generally exhibit an accumulation of $\mathrm{Na}^{+}$ and $\mathrm{Cl}^{-}$and/or the reduced uptake of mineral nutrients, especially $\mathrm{Ca}^{++}, \mathrm{K}^{+}, \mathrm{N}$ and $\mathrm{P}$ (Kaya et al., 2001). In this regard, a soluble source of $\mathrm{Ca}^{++}$is essential for reclamation of such soils, which is helpful in removing harmful $\mathrm{Na}^{+}$from the exchange complex and subsequently leached down from the root zone as drainage water. The use of gypsum, calcite, calcium chloride and other chemical agents that provide $\mathrm{Ca}$ tends to replace exchangeable $\mathrm{Na}$, is effective for saline soil amelioration (Hanay et al., 2004). Another important practice is the application of organic matter conditioners, which can both ameliorate and increase the fertility of saline soils (Melero et al., 2007). Salt affected soils generally exhibit poor structural stability due to low organic matter content. Many researchers have suggested that the structural stability of soil can be improved by the addition of organic materials (Oo et al., 2013). Rice straw and cowdung are the farm products which can be used for reclamation of saline soils as it offers an opportunity to improve the physical conditions of the soil and also to some extent improves soil fertility. Research has not been conducted on the effect of integrated use of gypsum, rice straw and cowdung amendments under field conditions. The objectives of the work were to evaluate the effects of different organic and inorganic amendments on soil salinity and fertility of saline soil as well as plant growth in the coastal areas of Bangladesh.

\section{Materials and Methods}

Field experiment was conducted at Satkhira $\left(22^{\circ} 48^{\prime} 40^{\prime \prime}\right.$, $88^{\mathrm{O}} 59^{\prime} 17^{\prime \prime}$ and $14 \mathrm{~m}$ above sea level), Bangladesh to observe crop yield and soil quality using organic and inorganic amendments during 2012-13. The initial soil was a loamy having pH 7.6, EC $960 \mu \mathrm{S} \mathrm{cm}^{-1}$, organic matter $1.76 \%$, total $\mathrm{N} 0.21$, available $\mathrm{P} 15.78 \mu \mathrm{g}^{-1}$, exchangeable K 0.26 meq $100 \mathrm{~g}^{-1}$ soil, respectively. Six treatments were: control (nitrogen $(\mathrm{N})$, phosphorus $(\mathrm{P})$, potassium $(\mathrm{K}) ; 80,50,40 \mathrm{~kg} \mathrm{ha}^{-1}$, respectively), gypsum (G) $\left(6 \mathrm{tha}^{-1}\right)$, cowdung $(\mathrm{CD})\left(6 \mathrm{t} \mathrm{ha}^{-1}\right)$, rice straw (RS) $\left(6 \mathrm{t} \mathrm{ha}^{-1}\right), 50 \%$ of $(\mathrm{CD}+\mathrm{G})$ and $50 \%(\mathrm{RS}+\mathrm{G})$. Field experiment was laid out in a randomized block design with three replications in a plot size of $8 \mathrm{~m}^{2}(4 \mathrm{~m} \times 2 \mathrm{~m})$ Nitrogen at $80 \mathrm{~kg} \mathrm{ha}^{-1}$ was applied through urea, half at 15 days after transplanting and the remaining half at maximum tillering stage, respectively. A basal dose of $\mathrm{P}$ and $\mathrm{K}(50,40)$ was applied through triple super phosphate and muriate of potash. According to treatments, rice straw, cowdung and gypsum were top dressed by placing it at the base of hill followed by hand mixing with soil before transplanting. About 30 days old rice seedlings transplanted at $15-\mathrm{cm}$ and $20-\mathrm{cm}$ inter row spacing. Soil samples were collected at the time of rice harvesting. Harvest index was calculated by using the following formula: Harvest index $=$ (Grain yield/ Biological yield) $\times 100$. Soil samples were dried, powdered and sieved through $2 \mathrm{~mm}$ sieve for analysis of $\mathrm{pH}$, organic carbon and $\mathrm{EC}$ and different nutrients. The $\mathrm{pH}$ of soil samples was measured in soil: distilled water 1:2.5 suspension with the help of $\mathrm{pH}$ meter and organic carbon was measured by Walkley and Black's chromic acid digestion method. EC was measured by the following standard method. Harvested plants were dried and ground by using a stainless steel mill. Total $\mathrm{N}$ was determined by the modified micro-Kjeldhal 
method. Chemical analysis was followed by microKjeldhal for total $\mathrm{N}$ and di-acid mixture $\left(4: 1 ; \mathrm{HNO}_{3}\right.$ : $\mathrm{HClO}_{4}$ ) for phosphorus and potassium and then analyzed using the method of Page et al. (1982). N use efficiency was derived by the following formula: [Nuptake (fertilized plot)] - [N-uptake (control)]/Rate of $\mathrm{N}$ applied $\times 100$, and agronomic efficiency was calculated by the formula: [Grain yield (fertilized)] - [grain yield (control)]/Rate of fertilizer applied in $\mathrm{kg}$. To test the difference among the treatments, randomized block design analysis of variance (ANOVA) was used with soil amendment treatments as the fixed factor, and experimental blocks as the random factor. The probability level used to determine significance was $\mathrm{p}<0.05$. Means were compared with an LSD test at $\mathrm{p} \leq 0.05$. Whenever (treatment effects were significant).

\section{Results and Discussion}

Yield contributing parameters were significantly influenced by organic and inorganic amendments (Table 1). The tallest plant height was found with $\mathrm{RS}+\mathrm{G}$ treated treatment. The lowest plant height was observed in rice treated plots. The increasing height of plant might be due to sufficient supply of nutrient during improvement of soil quality by organic and chemical amendments. The maximum and minimum total tillers were found in $50 \%(\mathrm{RS}+\mathrm{G})$ and control treatments, respectively. Highest effective tillers were observed in $50 \%(\mathrm{RS}+\mathrm{G})$ treatment that was similar to gypsum treated treatment. The highest filled grains panicle ${ }^{-1}$ was recorded in $50 \%(\mathrm{RS}+\mathrm{G})$ treatment that was similar to $50 \%$ (cow dung + gypsum $; \mathrm{CD}+\mathrm{G}$ ) treatment. Lowest number of grains panicle ${ }^{-1}$ was found in cow dung treatment. Maximum 1000 grains weight was obtained from $50 \%(\mathrm{RS}+\mathrm{G})$ treatment. Similar result was also obtained by Shivay and Singh (2003).

Grain and straw yield were significantly affected by different treatments (Table 1). The highest grain yield was recorded with $50 \%(\mathrm{RS}+\mathrm{G})$ treatment that was statistically similar to $50 \%(\mathrm{CD}+\mathrm{G})$ treatment. The application of rice straw in combination with gypsum showed a positive effect on the yield components of rice. Different treatments significantly increased effective tillers hill ${ }^{-1}$ and grains panicle ${ }^{-1}$ which might have the contribution to the highest grain yield. Grain yield in cowdung treated plots was higher than rice straw treated plots due to significant reduction in fertile tillers hill ${ }^{-1}$.

Table 1. Effect of organic and inorganic amendments on yield and yield contributing characters of rice

\begin{tabular}{lccccccccc}
\hline Treatment & $\begin{array}{c}\text { Plant } \\
\text { height } \\
(\mathrm{cm})\end{array}$ & $\begin{array}{c}\text { Panicle } \\
\text { length } \\
(\mathrm{cm})\end{array}$ & $\begin{array}{c}\text { Total } \\
\text { tillers } \\
(\text { No. })\end{array}$ & $\begin{array}{c}\text { Effective } \\
\text { tillers } \\
(\text { No. })\end{array}$ & $\begin{array}{c}\text { Filled } \\
\text { grains } \\
(\text { No. })\end{array}$ & $\begin{array}{c}\text { 1000 seeds } \\
\text { weight } \\
(\mathrm{g})\end{array}$ & $\begin{array}{c}\text { Grain } \\
\text { wt } \\
\left(\text { tha }^{-1}\right)\end{array}$ & $\begin{array}{c}\text { Straw } \\
\text { wt. } \\
\left(\text { tha }^{-1}\right)\end{array}$ & $\begin{array}{c}\text { HI } \\
(\%)\end{array}$ \\
\hline Control & 88.87 & 20.33 & 9.13 & 8.13 & 45.60 & 22.59 & 2.97 & 3.12 & 48.77 \\
Gypsum (G) & 89.60 & 20.07 & 10.20 & 9.40 & 47.00 & 22.43 & 3.53 & 4.35 & 45.37 \\
Cowdung (CD) & 89.20 & 19.20 & 9.17 & 8.33 & 41.40 & 22.22 & 3.36 & 3.55 & 48.63 \\
Rice straw (RS) & 88.20 & 19.80 & 9.53 & 7.83 & 48.80 & 22.66 & 2.26 & 2.76 & 45.02 \\
$50 \%(\mathrm{CD}+\mathrm{G})$ & 89.80 & 20.80 & 10.00 & 9.53 & 61.12 & 22.55 & 4.30 & 4.36 & 49.65 \\
$50 \%(\mathrm{RS}+\mathrm{G})$ & 90.33 & 21.00 & 11.40 & 10.00 & 63.45 & 22.60 & 4.64 & 5.36 & 46.40 \\
\hline LSD $_{0.05}$ & 1.51 & 0.80 & 1.07 & 1.00 & 4.84 & NS & 0.66 & 0.12 & NS \\
\hline
\end{tabular}

notes : LSD=Least Significant Difference, NS=Non-significant, HI=Harvest index

The average increase of grain yield was $1.33 \mathrm{t} \mathrm{ha}^{-1}$ $(45 \%)$ using $50 \%(\mathrm{CD}+\mathrm{G})$ while combined use of $50 \%$ $(\mathrm{RS}+\mathrm{G})$ showed the increase of $1.67 \mathrm{t} \mathrm{ha}^{-1}(56 \%)$ compared to control treatment. Similar trend was found in straw yield of rice. The highest straw yield was obtained with $50 \%(\mathrm{RS}+\mathrm{G})$ treatment. The lowest straw yield was found in rice straw treated treatment. Rice straw incorporation into the soil contributes to reducing condition in the rice field and possible negative impacts on rice growth. Because straw incorporation into the soil reduces oxygen and increases toxic carbon compounds (Ruensuk et al., 2010). Chemical fertilizer didn't produce significant amount of paddy yield. Continuous uses of chemical fertilizers even in balanced proportion don't able to sustain crop productivity due to deterioration in soil fertility. These results are in agreement with to Zia et al. (2000). The highest harvest index was observed in $50 \%(\mathrm{CD}+\mathrm{G})$ treated plots and the minimum harvest index was obtained from rice straw treated plots.

Nutrients content (N, P and $\mathrm{K}$ ) in grain and straw of rice are shown in Fig. 1. Maximum $\mathrm{N}$ content in grain and straw was obtained from $50 \%(\mathrm{RS}+\mathrm{G})$ treated plots and the lowest was found in control treated plots, respectively. The highest $\mathrm{P}$ content in grain and straw was found in cowdung and $50 \%(\mathrm{RS}+\mathrm{G})$ treated plots and the lowest phosphorus content was obtained from $50 \%(\mathrm{CD}+\mathrm{G})$ and cowdung treatments, respectively. The highest $\mathrm{K}$ content in grain and straw was found in rice straw and control treated plots, respectively. Nutrients uptake in grain and straw were significantly influenced by organic and inorganic amendments (Table 2). The highest $\mathrm{N}, \mathrm{P}$ and $\mathrm{K}$ uptake in grain and straw was found in $50 \%$ of $\mathrm{RS}+\mathrm{G}$ treatment except phosphorus uptake in grain. Maximum $\mathrm{N}$ uptake in grain and straw was recorded in the treatment receiving $50 \%$ of $\mathrm{RS}+\mathrm{G}$ whereas, the minimum $\mathrm{N}$ uptake of grain and straw was for rice straw treatment, respectively. The integrated use of organic and inorganic amendments had significantly influenced the $\mathrm{P}$ uptake in grain and straw of rice. Maximum $\mathrm{P}$ uptake was recorded in cowdung and $50 \%(\mathrm{RS}+\mathrm{G})$ treated plots. The results showed that $\mathrm{N}$ and $\mathrm{P}$ uptake of rice increased with the integrated use of organic and chemical amendments. $\mathrm{K}$ uptake of straw was significantly affected by different treatments (Table 2). In case of grain and straw the maximum $\mathrm{K}$ uptake was observed in $50 \%(\mathrm{RS}+\mathrm{G})$ treatment, In grain and straw 
the lowest amount of $\mathrm{K}$ uptake was observed in

depended on yield and nutrient content of rice. cowdung treated plots. Amount of nutrient uptake

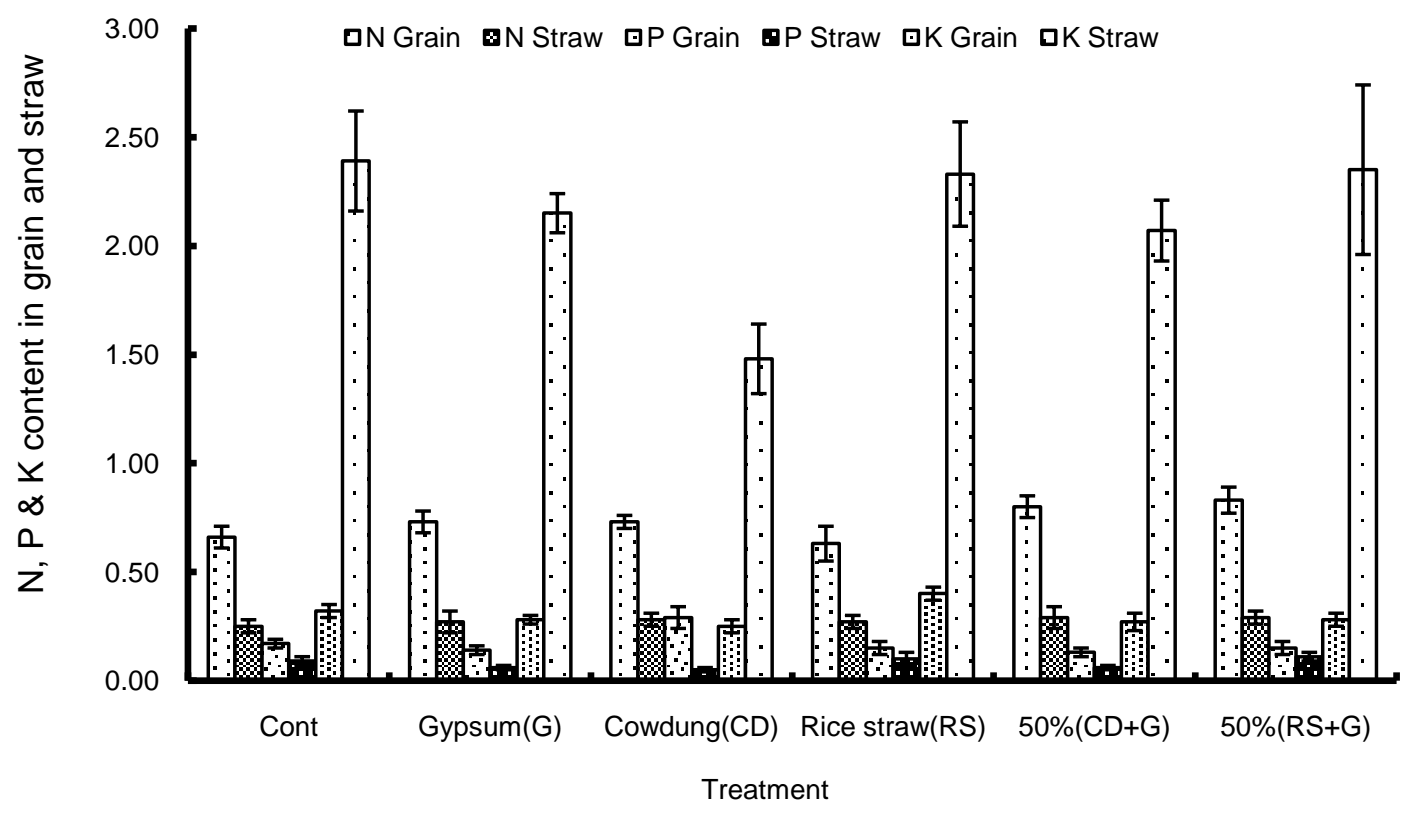

Fig. 1. Effect of organic and inorganic amendments on N, P \& K content in grain and straw of rice (standard error : vertical bar)

In this study, the highest grain and straw yield was observed in $50 \%(\mathrm{RS}+\mathrm{G})$ treatment. Organic amendment improved soil physical conditions which helped to reduce leaching losses, prolong nutrient availability, and synchronize nutrient release with crop demand. Similar findings reported by Sengar et al. (2000) who described that N, P, K uptake by rice was significantly increased by the application of $\mathrm{N}$ fertilizer and manure.

Table 2. Effect of organic and inorganic amendments on nutrient uptake, $\mathrm{N}$ use efficiency and agronomic efficiency of rice

\begin{tabular}{|c|c|c|c|c|c|c|c|c|}
\hline \multirow[t]{2}{*}{ Treatment } & \multicolumn{2}{|c|}{$\begin{array}{c}\text { Nitrogen uptake } \\
\left(\mathrm{kg} \mathrm{ha}^{-1}\right)\end{array}$} & \multicolumn{2}{|c|}{$\begin{array}{l}\text { Phosphorus uptake } \\
\left(\mathrm{kg} \mathrm{ha}^{-1}\right)\end{array}$} & \multicolumn{2}{|c|}{$\begin{array}{c}\text { Potassium uptake } \\
\left(\mathrm{kg} \mathrm{ha}^{-1}\right)\end{array}$} & \multirow{2}{*}{$\begin{array}{c}\text { Agronomic } \\
\text { efficiency } \\
(\mathrm{kg} / \mathrm{kg})\end{array}$} & \multirow{2}{*}{$\begin{array}{c}\mathrm{N} \text { use } \\
\text { efficiency } \\
(\%)\end{array}$} \\
\hline & Grain & Straw & Grain & Straw & Grain & Straw & & \\
\hline Control & 19.60 & 7.80 & 5.15 & 2.91 & 9.50 & 74.67 & - & - \\
\hline Gypsum (G) & 25.77 & 11.90 & 6.12 & 2.47 & 9.88 & 93.24 & 12.83 & 7.00 \\
\hline Cowdung (CD) & 24.53 & 9.94 & 9.52 & 1.85 & 8.29 & 52.63 & 5.35 & 2.95 \\
\hline Rice straw (RS) & 14.24 & 7.45 & 4.07 & 2.73 & 9.06 & 64.38 & -5.12 & -6.37 \\
\hline $50 \%(\mathrm{CD}+\mathrm{G})$ & 34.40 & 12.64 & 5.73 & 2.62 & 11.75 & 90.25 & 18.53 & 12.55 \\
\hline $50 \%(\mathrm{RS}+\mathrm{G})$ & 38.51 & 15.54 & 7.73 & 5.72 & 12.84 & 126.14 & 27.84 & 17.44 \\
\hline $\mathrm{LSD}_{0.05}$ & 2.57 & 1.55 & NS & 1.86 & $\mathrm{NS}$ & 29.52 & - & - \\
\hline
\end{tabular}

notes : LSD=Least Significant Difference, NS=Non-significant

Agronomic use efficiency as affected by organic residues and chemical amendment alone or their combination is presented in Table 2. The maximum agronomic efficiency was observed in the treatment of $50 \% \mathrm{RS}+\mathrm{G}$ followed by the treatment of $50 \% \mathrm{CD}+\mathrm{G}$. The high agronomic efficiency might be due to the reason that amendment (rice straw and cowdung) changed in soil quality and are linked to the effects of OM content on soil structure and biological activity (Bronick and Lal 2005). Soil quality and good soil management are vital components of sustainable crop production because soil supports the fundamental physical, chemical, and biological processes that must take place in order to support plant growth and ultimately increased yield. Comparing the individual sources, rice straw produced negative agronomic efficiency over control treatment. Incorporation of rice straw into soil can be enhanced through microbial $\mathrm{N}$ immobilization due to its high $\mathrm{C}: \mathrm{N}$ ratio (Shindo and Nishio 2005). Nitrogen use efficiency (NUE) as affected by various organic and amendment and their combination are presented in Table 2. Significant 
differences were observed in $\mathrm{N}$-use efficiency, and maximum NUE was observed in the treatment where $50 \%$ RS + G was applied followed by the treatment where $50 \% \mathrm{CD}+\mathrm{G}$ was used. Organic sources as cowdung also resulted in lesser NUE than the treatment where only gypsum was applied as amendment. Comparing the individual sources, rice straw produced negative agronomic efficiency over control treatment. Quality ( $\mathrm{pH}, \mathrm{EC}$ and organic matter) of post harvest soil was not statistically significant among the treatments. Gypsum increased the soil pH compared to control (Fig. 2). Maximum $\mathrm{pH}$ reduction was obtained in rice straw treated plots. Decrease in $\mathrm{pH}$ could be due to the addition of rice straw as an organic amendment. Organic amendments decreased soil $\mathrm{pH}$ due to adsorption of $\mathrm{H}^{+}$by their specific negative surface areas. The maximum EC value was observed in control treatment and the lowest EC value was found in gypsum treatment. Decrease in EC could be due to removal of excess $\mathrm{Na}^{+}$from their exchange complex sites. The highest organic matter content was found in rice straw treatment, and the lowest organic matter was observed in gypsum and $50 \% \mathrm{RS}+\mathrm{G}$ treatments. In $50 \% \mathrm{CD}+\mathrm{G}$ treated plots, plant growth was better than control and as a result of gypsum treatments, OM decomposition was higher than control.

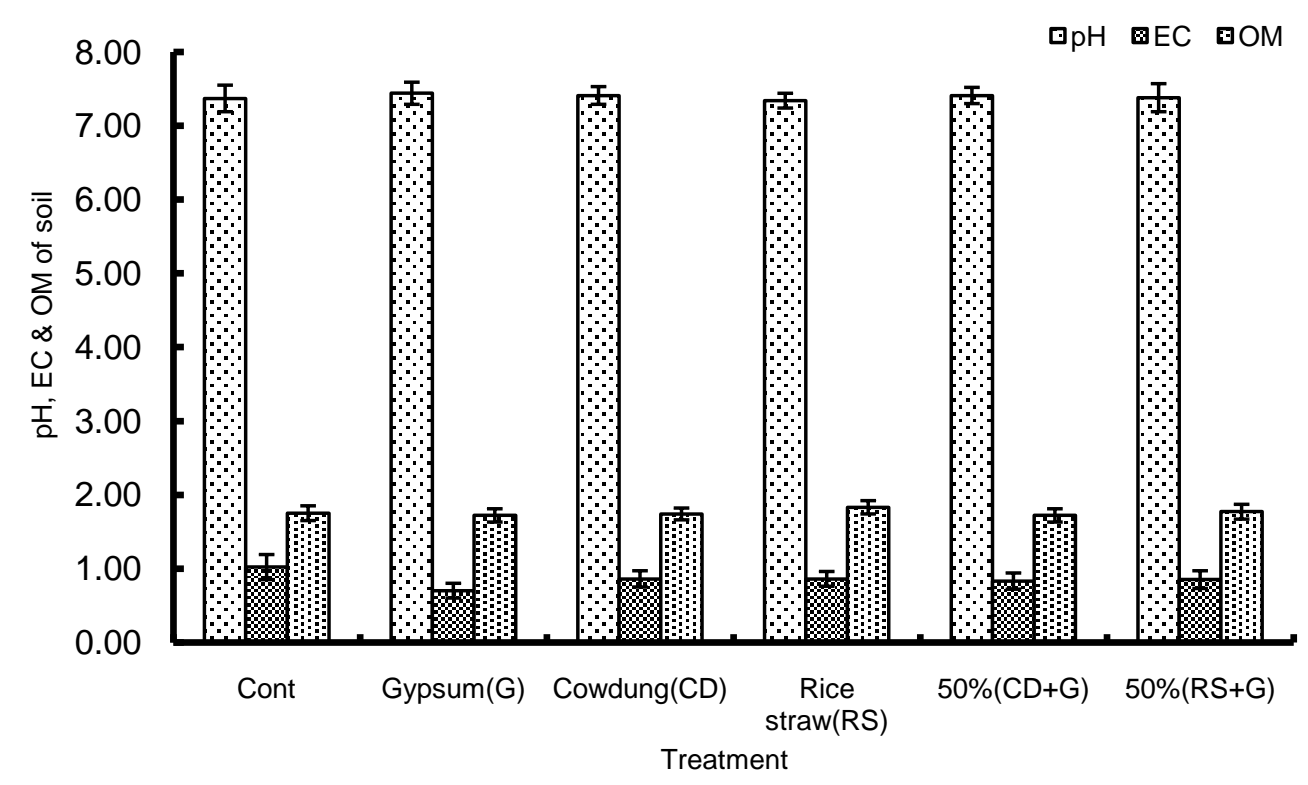

Fig. 2. Effect of organic and inorganic amendments on $\mathrm{pH}, \mathrm{EC}$ and organic matter in soils (standard erorr : vertical bar)

Based on the results, $50 \% \mathrm{RS}+\mathrm{G}$ amendments could be recommended to mitigate soil salinity thereby improving the crop productivity in the salt affected lands. It could be concluded that rice straw or cowdung in combination with gypsum is sufficient and equally effective to enhance the vegetative growth, increased

\section{References}

Bronick, C. J. and R. Lal. 2005. Soil structure and management: A review. Geoderma. 124: 3-22.

Hanay, A. F.; Buyuksonmez, F. M. and Kanbolat, M. Y. 2004. Reclamation of saline-sodic soils with gypsum and MSW compost. Compost Science and Utilization. 12: 175-179.

Haque, S. A. 2006. Salinity problems and crop production in coastal regions of Bangladesh. Pak. J. Botany. 38: 1359-1365.

Kaya, C.; Kimak, H. and Higgs, D. 2001. Enhancement of growth and normal growth parameters by foliar application of potassium and phosphorus in tomato cultivars grown at high $(\mathrm{NaCl})$ salinity. Journal of Plant Nutrition. 24: 357-367. number of effective tiller and grain yield of rice. The results are in agreement with those of Sultan et al. (2007). Moreover, 50\% RS + G amendment could be recommended to mitigate soil salinity and thereby, improving the crop productivity in the salt affected soils.

Melero, S.; Madejon, E.; Ruiz, J. C. and Herencia, J. F. 2007. Chemical and biochemical properties of clay soil under dryland agriculture system as affected by organic fertilization. European Journal of Agronomy. 26: 327-334.

Oo, A. N.; Iwai, C. B. and Saenjan, P. 2013. Soil properties and maize growth in saline and nonsaline soils using cassava-industrial waste compost and vermicompost with or without earthworms. Land Degradation and Development. DOI: 10.1002/ldr.2208.

Page, A. L.; Miller, R. H. and Keeney, D. R. 1982. Methods of Soil Analysis. Part 2: Chemical and Mineralogical Properties. Agronomy monograph no. 9 ASA-SSSA Madison, Wisconsin. 
Qadir, M.; Oster, J. D.; Schubert, S.; Noble, A. D. and Sahrawat, K. L. 2007. Phytoremediation of sodic and saline-sodic soils. Advances in Agronomy. 96: 197-247.

Ribeiro, M. V.; Deuner, S.; Benitez, L. C.; Einhardt, A. M.; Peters, J. A.; and Braga, E. J. B. 2014. Betacyanin and antioxidant system in tolerance to salt stress in Alternanthera philoxeroides. Agrociencia. 48: 199-210.

Ruensuk, N.; Mongkonbunjong, P. and Inthaleang, W. 2010. Effect of rate of straw incorporation into the soils on rice growth and yield. In: Soil Solutions for a changing World, Gilkes RJ and Prakongkep N (Eds), pp. 140-142. Proc. 19 $9^{\text {th }}$ World Congress of Soil Science, 1-10 August, 2010. Brisbane, Australia.

Sengar, S. S.; Wade, L .J.; Baghel, S. S.; Singh, R. K. and Singh, G. 2000. Effect of nutrient management on rice in rainfed low land of Southeast Madhya Pradesh. Indian J. Agronomy. 45: 315-322.

Shindo, H. and Nishio, T. 2005. Immobilization and remineralization of $\mathrm{N}$ following addition of wheat straw into soil: determination of gross $\mathrm{N}$ transformation rates by ${ }^{15} \mathrm{~N}$-ammonium isotope dilution technique. Soil Biology Biochemistry. 37: 425-432.

Shivay, Y. S. and Singh, S. 2003. Effect of planting geometry and nitrogen level on growth, yield and nitrogen use efficiency on scented hybrid rice (Oryza sativa L.). Indian J. Agronomy. 48: 42-44.

Sultan, M. I.; Gill, M. A.; Anwar, M. M. and Athar, M. 2007. Evaluation of soil physical properties as influenced by various legumes and phosphorus fertilization under rainfed conditions. Int'l. $J$. Environ. Sci. Technology. 4: 109-118.

Sumner, M. 2000. Handbook of Soil Science. Boca Raton : Chemical Rubber Company (CRC) Press. p. 2148.

Zia, M. S.; Mann, R. A.; Aslam, M.; Khan, M. A. and Hussain, F.. 2000. The role of green manuring in sustaining rice-wheat production. National Fertilizer Development Centre, Islamabad. Pakistan.In: Integrated Plant Nutrition Management, Eds. Ahmad N and Hamid A (Eds), pp. 130-149. 